\title{
PAROCHIALISM ON THE BAY: AN ANALYSIS OF LAND USE PLANNING IN THE SAN FRANCISCO BAY AREA $\dagger$
}

In 1926, the United States Supreme Court held municipal planning and land use regulation to be a valid exercise of state police power. ${ }^{1}$ Since that date, thousands of cities and counties have created master plans and zoming ordinances. These attempts to regulate land use frequently fail to meet the needs of the particular locality. ${ }^{2}$ Nowhere is this failure more pronounced than in the huge metropolitan centers of this country where dozens of cities and counties border upon and overlap each other. Further, while forces of social and economic integration lave made the cities and counties within these centers more interdependent, each jurisdiction continues to determine its land use policies without regard for the effects such policies may have on other jurisdictions within the metropolitan area.

The development of the San Francisco Bay Area ${ }^{3}$ lias made it uniquely susceptible to the wasteful effects of this parochialism. First, the various geographical sectors of the Bay Area have grown in radically different ways. ${ }^{4}$ San Francisco emerged before the mass transit era. Since the population had to live close to work, homes were often compressed into small areas. Consequently, the inner city still has an extremely dense population. The cities in San Mateo and Marin counties settled along rail lines which tied them together, like a string of beads running along the bay. The central core of the East Bay developed around a trolley system, as though clustered along the spokes of a wheel. Recently, the South Bay and newer

$\dagger$ This Comment is a product of traditional legal research and a limited number of field interviews. Summaries of each interview are on file in the offices of the California Law Review. Because many of those interviewed requested that they not be identified, each interview has been given a code number by which it will be cited in the footnotes. In the code numbers, $\mathrm{L}$ means local city planners, $\mathrm{R}$ means regional planners, and $\mathrm{P}$ means professional planning consultants not officially responsible for the formulation of any plans.

1 Village of Euclid v. Ambler Realty Co., 272 U.S. 365 (1926). To overcome the argument that zoning was a taking of private property without just compensation, the court analogized zoning ordinances to the familiar common law primciples of public nuisance. It stated that a "nuisance may be merely the right thing in the wrong place,-like a pig in the parlor instead of the barnyard," id. at 388, and concluded that "apartment houses, which in a different environment would be not ouly entirely unobjectionable but highly desirable, come very near to being nuisances." Id. at 395.

Today it is no longer necessary to rely on the nuisance doctrine. Zoning is accepted as valid under the police power. See, e.g., Johnson v. City of Claremont, 49 Cal. 2d 826, 323 P.2d 71 (1958).

2 For an interesting discussion of the failures of early zoning techniques see, Bair, Is Zoning a Mistake? 14 ZonIng Dic. 249 (1962).

3 The Bay Area is usually taken to include the territory of the nine Bay Area counties: Alameda, Contra Costa, Marin, Napa, San Francisco, San Mateo, Santa Clara, Solano and Sonoma.

${ }^{4}$ See J. Vance, Geography and Urban Evolution in the San Francisco bay area 33-36, 42-67 (1964). 
East Bay communities, increasingly dependent upon the automobile and thus characterized by population dispersion, have sprouted up in a random manner.

These varied types of settlement have different land use needs and display different patterns of land use regulation. San Francisco, for example, has been able to zone entire sections of the city solely for commercial purposes, isolating this activity from residential and industrial sectors. But in the urban core of the East Bay, the commercial zone parallels old trolley lines which are now the main arteries of the city, penetrating residential areas which grew up around the lines. And the newer communities have himited commercial activity and are able to spot zone commercial areas throughout the jurisdiction, wherever it is most convenient for local residents.

Second, the recent trend in population growth has caused disparities in required services and available resources. The tremendous population growth in the Bay Area las occurred outside its traditionally urban centers, ${ }^{5}$ and, as incomes rise, people move out of the central cities to suburbs where they may enjoy better living conditions. The central cities are left with low income residents who move into the old louses abandoned by the vacating middle and upper classes. ${ }^{6}$ These remaining residents are unable to supply the necessary tax revenues to maintain the previous level of city services. As a result the central cities become infested with slum areas wlich consume a disproportionate amount of the limited city services. This move to suburbia means that core cities suffer the effects of problems caused by the population explosion, without being able to deal with them at their source.

Third, the extremely diverse geographic and climactic conditions in the Bay Area lrave encouraged the isolation of many communities. Hills in all counties lave caused initial city growth in separated valleys; the Golden Gate, the Carquinez Straits, and other waters of the bay, have tended to physically separate localities; and varied climactic conditions lave attracted persons to some areas, while discouraging them from others. ${ }^{7}$ Fourth, various economic functions lave developed in different parts of the region. San Francisco became the financial and wholesale

5 Between 1950 and 1960 the population of the entire Bay Area increased from 2,153,300 to 3,216,700. K. Davis \& E. Langlois, Future Demograptutc Growtin of the San FranCTSCO BAY AREA 7 (1963). But during this same period, the combined populations of San Francisco, Oakland, Berkeley and Alaneda decreased froin 1,338,167 to 1,282,987. J. Varce, supra note 4 , at 46 . Growth outside the traditional urban center is also evident from the number of houses built in the 1950-60 period. While in older cities the growth was about $28 \%$, the growth in the newer cities was over $58 \%$. C. WURSTER, HousIng AND THE FUTURE of Citres in the San Franctsco Bay Area 19 (1963).

${ }^{6}$ See R. Vernon, The Myth and Realtty of OUr Urban Problems (1962).

7 See J. VANCE, supra note 4, at 4-35. 
center, ${ }^{8}$ the East Bay developed into industrial commumities, ${ }^{0}$ and the Northern Counties remained agricultural. The natural result of these diversities has been for each locality to concentrate upon its own problems without regard to regional needs.

This lack of cooperation in Bay Area land use planning may not have been a problem in the past when communities had the space to develop in comparative isolation. But the Bay Area of the future may not be afforded that luxury. Bay Area population will increase rapidly-from $3,638,939$ in 1960 to $7,207,000$ in $1990 ;{ }^{10}$ and the territory covered by the metropolitan Bay Area will also expand-from 1,286 square miles in 1960 to 6,017 square miles in $1990 . .^{11}$ Each community will figlit for its sliare of growth, but only the "right kind" of growth. People will work in one city and live in another. ${ }^{12}$ Actions taken by one jurisdiction will have region-wide ramifications on housing, transportation, air and water pollution, and recreation. The problems are regional because they affect more than one jurisdiction and their solution requires the cooperation of two or more jurisdictions.

In this context, parochial planning creates unnecessary regional costs. If City $A$ invites a large industry to settle within its boundaries and at the same time fails to provide housing for the people thus employed, large scale commuting will become necessary. This commuting may put a burden on existing transportation routes, necessitating the construction of additional freeways through Cities $B, C$, and $D$ who had no voice in the decision to establish the industry in City $A$. City $E$, which provides housing for the workers of City $A$, has no recreation facilities. As a result residents of City $E$ must commute to City $F$ to enjoy a weekend picnic in a park paid for by the residents of City $F$. And as a result of all this commuting, exhaust fumes cause severe air pollution problems for all residents of the region. These regional costs will continue to grow as long as local decisions are based on parochial policies. Successful future planning, therefore, requires an understanding of those forces which currently should determine land use regulation in the Bay Area.

This comment examines the extent to which each level of government

8 Id. at $18-22$.

9 Id. at $57-59$.

10 Assoctation of Bay Area Governacents, Prestminary Regtonat Pian for the San Francisco Bay Region 9 (1966) [hereinafter cited as ABAG, Preltminary Plan]. A recent study by the California Parks and Recreation Department indicates that by 1980 seven Bay Area counties (Napa and Sonoma excluded) will have populations of 6.2 million. San Francisco Chronicle, March 21, 1967, at 4, col. 6. For an even higher estimate see

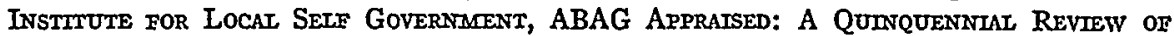
Voluntary Regtonal Co-operattve Action Throdgr the Assoctation of Bay Area Governarents 13 (1965) [hereinafter cited as ABAG Appraised].

$11 \mathrm{~K}$. Davis \& E. Langlors, supra note 5 , at 26.

12 See J. VANCE, supra note 4 , at 83 . 
in California - state, regional and local - has effectively realized local land use objectives. Part I explores in depth local approaches to land use planning. It first discusses the general requirements for local land use planning and the procedure by which these requirements are put into practice. It then describes the problems that exist in Bay Area planning and analyzes their causes. Part II examines the procedures, powers and inadequacies of State and regional approaches to local land use planning. It concludes that attempts to plan on these levels have failed to cope with those contemporary problems demanding regional solution.

\section{I}

\section{IOCAL PIANNING}

Two basic tools of land use planning are frequently confused: comprehensive zoning and general planning. A clearly drawn distinction between the two is essential to any discussion of the problems connected with control of urban growth. ${ }^{13}$ Zoming is the "separation of the inunicipality into districts, and the regulation of buildings and structures in the district so created, in accordance with their construction and the nature and extent of their use."14 General planning, on the other hand, is a broader concept. A general plan is a comprehensive and coordinated guide for the future development of the community. It represents the nearest approach to a general agreement on the future objectives and development of the community which can be achieved in hight of constraints on the community's size and potential economic and social growth.

General planning is where you want to go and zoning is how you get there. They are fundamentally interrelated. General planning without zoning lacks the implementing force to attain desired ends. "[Z]oming without planning lacks the coherence and discipline in the pursuit of goals of public welfare which the whole municipal regulatory process is supposed to serve." 15

\section{A. The Local Planning Process}

\section{State Requirements}

The California legislature has failed to require zoning to be in accordance with a general plan. ${ }^{16}$ The legislature has provided, for example, that

13 Zoning and planning are only two of many ways to control urban growth. Urban redevelopment, subdivision and building code regulation, and capital improvements prograns, for example, are necessary to make zoning and planning fully effective. For an indication of the tools one Bay Area city considers necessary for urban development, see The Master Plan of the City of Berkeley, ch. XI (1955).

14 Mansfield \& Swett, Inc. v. Town of West Orange, 120 N.J. 145, 149, 198 A. 225, 228 (Sup. Ct. 1938).

15 Haar, In Accordance with a Comprehensive Plan, 68 HaRv. L. Rev. 1154 (1955).

${ }^{16}$ See Haar, supra note 15, at 1154: "[T]he relationship between the zoning ordinance and its parent, the overall ... plan, has been explored surprisingly seldom by ... legis- 
all local planning agencies "shall develop and maintain a general plan."17 But this directive is virtually meaningless because no sanctions are imposed for failure to "develop" a plan. Moreover, while local legislatures are required to "adopt," after due consideration, the agency's plan, ${ }^{18}$ there is no time limit within which the locality is required to "adopt" the proposed plan. ${ }^{19}$ These provisions, therefore, are only legislative suggestions to California communities that they zone with respect to longrange goals and objectives. They have no binding force. ${ }^{20}$

Cities are presently able to pass zoning ordinances without any reference to the long-range objectives embodied in a general plan. ${ }^{21} \mathrm{Com}$ munities apparently feel that once they lave comprehensively zoned every parcel of land in the jurisdiction, there is no further need for any long-range planning. ${ }^{22}$ This approach is clearly evident in the Bay Area. Althougl most cities and counties lave comprehensive zoning ordinances, over one-half of the counties have failed to adopt any general plan for their entire jurisdiction. ${ }^{23}$

The unfortunate consequences of failure to zone in accordance with a general plan are illustrated by the great overextension of industrial zoning in the Bay Area over the past decades. In the western portions of Alameda and Contra Costa counties, ${ }^{24}$ for example, large areas were zoned for industrial use. Each jurisdiction hoped to attract industry to provide tax dollars necessary to support the desired level of governmental goods and services for its residents. Not until later, when Master Plan forecasts were

latures; and there is an apparent tendency to lose sight of the very fact that a fundamental and necessary interrelation exists."

17 CaI. Gov't Code $\S 65101$ (a) (West 1966).

18 Id. $\S \S 65350-60$.

19 See 4 OP. Car. Atr'y Gen. 150 (1944). Thus a community may, if it wishes, legally avoid adopting a general plan without violating the legislative mandate as long as it can show that it plans to adopt a plan sometime in the future.

20 See Car. Gov's CODE $\S 65860$ (West 1966). Although the state legislature apparently does not appreciate the importance of planning before zoning, it has recognized this connection in other areas. In the field of urban renewal, for example, each step of the renewal plan must conform to the general plan. If a plan does not exist, then a renewal program cannot be maintained. See Comment, 55 CAIIF. L. REv. 813, 816 (1967).

21 Indeed, this has been a frequent approach to planning. Over half the cities in the nation that have adopted zoning ordinances have not yet adopted any general plans. $B$. Pooley, Planning and Zoning in the United States 6 (1961).

22 See Haar, supra note 15, at 1156.

23 Almost all of Solano, Sonoma and Marin counties and substantial sections of eastern Contra Costa and Alameda counties do not have general plans. See ABAG, Preuninary PLAN, supra note 10, at 23. (Composite map of all general planning in the Bay Arca.) Cities have also been lax in adopting general plans. El Cerrito, for example, only adopted a preliminary plan in April 1967. Berkeley Daily Gazette, April 4, 1967, at 1, col. 5.

24 See ABAG, Precmanary Plan, supra note 10, at 18. Compare present land use in 1965 , id. at 17 , with permitted land use in $1965, i d$. at 19 , for a graphic representation of industrial overzoning. 
made to estimate the industrial potential for each area, was it discovered that more land was set aside for industry than industry could possibly use. Unfortunately, the discovery came too late; enough industry had moved in to make the areas undesirable for residential communities, but not enough to provide an adequate tax base. ${ }^{25}$

If the legislature were to require that all zoning ordinances conform to an "adopted" general plan, shortsighted planning might occur less frequently. Jurisdictions would be required to decide what they want to do before they do it.

The requirement of a general plan would also supply the courts with a workable standard for determining the validity of a zoning ordinance. Today, courts will only determine whether the regulations bear a reasonable relation to "the health, safety, morals, or general welfare of the community." ${ }^{26}$ A heavy presumption exists in favor of the regulations. ${ }^{27} \mathrm{Be}-$ cause there is no definite standard to determine what is reasonable, courts will overturn zoning ordinances only if they are clearly arbitrary and oppressive. ${ }^{28}$ But if a general plan were required, a court would overturn any zoning regulation that was not in accordance with the general plan. Any such regulation would be unreasonable per se. ${ }^{29}$ The court would no longer be confined to determining the validity of zoning regulations by deciding whether they were "arbitrary and oppressive."30

Until the legislature gives some direction in this area, localities will be free to enact land use regulations without any regard to the long range effects of their pohicies on themselves and the region as a whole. The only controls on local land use planning will continue to be those provided by local planning procedures.

25 Interview No. 8-L. The reason zoning before planning has caused so much trouble is that cities, like Oakland and Berkeley, do not require amortization of nonconforming uses. Therefore, even if the zone is changed to conform to the new general plan, industrial structures built under old zoning regulations are allowed to remain until they fall apart. In fact the city council in Berkeley almost gave owners of nonconforming uses the opportunity to rebuild if the structure was for any reason destroyed. This would have removed all possibility of ridding the area of unwanted structures. A proposal is now before the council to forbid any repairing or remodeling of nonconforming uses once they fall below minimum building code regulations. This proposal would assure at least some type of amortization of non-conforming uses. See Interview No. 7-I.

${ }^{26}$ Roney v. Board of Supervisors, 138 Cal. App. 2d 740, 745, 292 P.2d 529, 532 (1956).

27 City of Los Altos v. Silvey, 206 Cal. App. $2 d$ 606, 24 Cal. Rptr. 200 (1962).

28 Metro Realty v. County of EI Dorado, 222 Cal. App. 2d 508, 35 Cal. Rptr. 480 (1963); Johnson v. City of Claremont, 49 Cal. 2d 826, 323 P.2d 71 (1958).

29 One commentator has argued that, even without this Iegislative requirement, "any zoning done before a formal master plan has been considered and promulgated is per se unreasonable, because of the failure to consider as a whole the complex relationships between the various controls which a mumicipality may seek to exercise over its inhabitants in furtherance of the general welfare." Haar, supra note 15, at 1174 .

30 See cases cited note 28 supra. 


\section{Local Procedures}

California planning statutes require each city and county to have a planning agency and each county to lave a planning commission. ${ }^{81}$ The commission must formulate general plans and implement them with zoning regulations. ${ }^{32}$ In so doing it inust hold public learings preceded by publication of adequate notice. ${ }^{33}$ Interested citizens may appear before the commission and voice their opinions concerning the proposed plan or ordinance. Once the commission is satisfied that the best plan or ordinance has been fornulated, it submits it as a recommendation to the local legislative body for approval. ${ }^{34}$ The legislative body then repeats the same hearing procedure before deciding whether to adopt the recommendation. Parties, therefore, are given a second opportunity to voice their objections. ${ }^{35}$

The adopted plan must contain two basic elements: a land use and a transportation elenent. The land use element must designate various parts of the jurisdiction for different uses, sucl as residential housing, commercial buildings, industrial development, and open spaces, and create desired standards for population and building densities in these areas. ${ }^{80}$ The transportation element must describe the proposed streets and highways that will run througl the district. ${ }^{87}$ Once the plan is adopted, no building nuy be constructed or street widened before the planning commission certifies that such action will be in accordance with the general plan. $^{38}$

81 CAL. Gov'T CODE $\$ 65100$ (West 1966). There is no statutory definition for an agency; it may be the local legislature, a planning commission or merely a staff of professional planners. A commission, on the other hand, is defined. It must consist of five to nine appointed officials who are responsible for the land use planming within the jurisdiction. Id. § 65150 .

The local legislative body can perform the commission's functions in cities without officially designated commissions. Id. $\$ \S 65358,65861$. Where the planning commission is not independent from the local legislative body, parties opposed to planning decisions cannot appeal the decisions to another governmental body. See text accoinpanying note 35 infra.

32 CAL. Gov't Code $\S \S 65101$ (a), 65800, 65903 (West 1966).

33 Id. $\$ \S 65351,65854$ require at least one public hearing with notice given through a newspaper of general circulation ten days in advance. If adequate notice of hearings is not given, all subsequent proceedings are void. William v. City of San Bruno, 217 Cal. App. 2d 480, 31 Cal. Rptr. 854 (1963).

34 CAL. Gov'T CODE $\$ \S 65354,65885$ (West 1966).

35 Id. $\S \S 65357,65854-57$.

36 Id. $₹ 65302$ (a). For permitted but not required elements of a general plan, see id. $\S 65303$. For a variation on required elements in the general plan see the Master Plan of the City of Berkeley, ch. X (1955).

37 CAL. Gov't Code $\&$ 65302(b) (West 1966).

${ }^{38}$ Id. $\$ 65402$ (a)-(b). Local state agencies, however, occupy a special position. Although they are required to submit their plans to the planning commission, they may disregard the commission's disapproval. Id. $\S 65402$ (c). This statutory loophole created many conflicts as the state created many new agencies. But rather than overrule $\S 65402$ (c), the legislature 
Within each individual jurisdiction existing notice and hearing procedures are sufficient to allow all interested citizens to voice their concerns. But the procedural safeguards of a hearing may be insufficient for effective representation if interested citizens lack the political power to assert their protests before the legislative bodies. ${ }^{39}$ To gain necessary political power for recognition, citizens have organized into interest groups. ${ }^{40}$ Although these groups may not always prevail, they will at least command the attention of the planning board.

\section{B. Problems in Local Planning in the Bay Area}

\section{Lack of Interjurisdictional Cooperation}

Even assuming all interest groups within the jurisdiction will be effectively heard and represented, problems remain. There is no procedure by which neighboring jurisdictions can influence the creation of plans and ordinances outside their jurisdiction even though such plans may markedly affect their own growth and development. ${ }^{41}$

Cooperation among neighboring jurisdictions is more essential in the Bay area than virtually anywhere else. Because so many mdependent jurisdictions border upon and overlap each other, the planning decisions of each will necessarily affect the growth and development of the region as a whole. Yet cooperation in Bay Area planning is almost nonexistent. The lack of interjurisdictional cooperation is not readily apparent, but the subtleness of the resulting failure makes it no less damaging to long term regional growth. Until 1966, for example, jurisdictions in the Bay Area could not even agree upon standardized zoning symbols to map existing land use regulations within each community so that each jurisdiction could understand how the others were zoned. ${ }^{42}$

superceded it with CAL. Gov'x CODE $\$ \S 53090-53095$. Today most, but not all, special districts must also obtain local planning commission approval before implementing their plans. See 37 Op. CaI. ATr'צ. GeN. 89 (1961). The fact that $\S 65402$ (c) was never overruled illustrates the chaos and complexity of California planning legislation.

30 Bay Area planners admit that local legislative bodies often ignore carefully prepared planning proposals because of pressure from individuals and groups with political influence. Interviews Nos. 8-I and 9-I.

${ }^{40}$ Examples of such permanent pressure groups are the West Berkeley Citizens Council and the North Oakland District Community Council. These groups represent the low income mimority groups within their respective communities and have enough influence to be beard effectively. Interviews 7-L and 10-L. Of course individuals who do not have group interests are not always represented or effectively lieard. If the problem affects only one person, as is necessarily the case with variance applications, he may not have sufficient influence to prevail. See Comment, Zoning: Variance Administration in Alameda County, 50 CALIF. L. REv. 101 (1962).

41 See notes 10-12 supra and accompanying text.

42 This information was compiled in 1966 by the planning staff of the Association of Bay Area Governments. Interview 1-R. 
The most obvious examples of lack of cooperation are found in the planning of circulation routes. A new highway, for example, is proposed for eastern Alameda and Contra Costa counties. According to the existing plan, however, the Contra Costa portion of the highway fails to intersect with the proposed highway in Alameda County. ${ }^{43}$ Similarly, on the west side of the Bay a freeway is planned between San Francisco and San Jose, except for a two to three mile gap in southern San Mateo County where no freeway is planned. If this gap is not corrected the freeway will be eliminated as a possible San Francisco to San Jose commuter stretch. ${ }^{44}$

Other examples are not so obvious. Once a jurisdiction has planned an area, neighboring jurisdictions are precluded, as a practical matter, from planning adjacent areas in a manner inconsistent with its neighbor. A prime example of this preclusion is the conflicting zoning of a border street between Berkeley and Oakland. Oakland has zoned the south side of the street for medium density apartments; ${ }^{45}$ Berkeley would like to zone its side of the street for single family residences. However, since the existence of higher density apartments across the street destroys the appeal and property value of smgle family dwellings, Berkeley has been forced to keep its side of the street zoned for apartments also. ${ }^{48}$

The significance of certain failures is not immediately apparent. Urban redevelopment relocation falls within this category. ${ }^{47}$ When San Francisco held hearings on the proposed redevelopment of the Mission District, ${ }^{48}$ present residents expressed the fear that they would have to move to new areas because reconstructed homes in the renewal area would become too expensive. Residents of the Mission District had good cause for alarm. This "pricing-out" method had been used all too effectively in San Francisco before, causing many former low income residents to move across the bay for suitable housing. ${ }^{49}$ Although this population shift obviously affected communities outside the redevelopment area, existing procedures gave them no voice in the relocation. ${ }^{50}$ San Francisco may

43 This gap was discovered only when the Association of Bay Area Governments, for the first time, combined all the individual city and county plans into one composite map. Apparently Contra Costa and Alameda had never conferred with each other on this matter. 44 See ABAG, Preltarnara Plan, supra note 10, at 23 (map of existing land use and circulation networks).

45 Oakland had zoned its side of the street for one unit per 1500 square fect, sufficient to support apartment buildings of six umits apiece.

46 Interview 7-L.

47 Because no records are kept on the families leaving the redevelopment area after the project's completion, it is impossible to tell why they left or where they went. Comment, 55 CaLIF. L. Rev. 813, 826-27 (1967).

48 For a discussion of the Mission District Redevelopment Project, see id. at 822 n.83823 n. 85 .

49 This was the method used in the Western Addition I redevelopment program in San Francisco. J. VaNcE, supra note 4 , at 87.

50 See Comment, supra note 47 , at 831-32, 817-18, 821-22. 
ameliorate its slum problems; but in so doing it forces other areas in the region to absorb a low income segment of the community and thereby shoulder the social and financial burdens such a responsibility entails.

The state has attempted, by adopting a referral statute, ${ }^{51}$ to build interjurisdictional cooperation into the planning process. Each jurisdiction "sliall" submit its plans to its neiglibors before they are adopted. This, lowever, is merely a formality, for the statute also provides that failure to refer proposed plans will not invalidate them when adopted. ${ }^{53}$

Even if referrals were mandatory, there still would be no effective means to resolve disputes among neigliboring jurisdictions. If Berkeley, for example, decided to zone for heavy industry an area which bordered on an Oakland residential district, Oakland would not be able to prevent it. Referral would only alert Oakland to the inevitable. At the most, Oakland could only argue that the proposed zoning would not be in Berkeley's best interest. ${ }^{54}$ It is evident, therefore, that referrals are unnecessary when two jurisdictions already find it in their own interest to cooperate and ineffective when they do not.

\section{Parochial Decision Making}

Failures in Bay Area interjurisdictional cooperation have been frequent. Parochial planning has been partly caused by decentralized decision making. This task has been divided between professional planners, inexpert planning commissioners and local politicians.

Local planning commissions have the initial legislative responsibility for drafting plans and zoning ordinances. ${ }^{55}$ The composition of local planming commissions is not prescribed by statute. Each commumity sets up its own standards for membership. The local legislature chooses commissioners who are "conscientious, well-meaning, public spirited,

51 CAL. Gov'T CODE $\$ \S 65305-06$ (West 1966).

52 Id.

53 Failure-to-comply provisions are often inserted in California planning legislation to satisfy a majority of legislators that the state is not imposing its will on local land use planning. See also, CAL. CORP. CODE $\S 3637$ (West 1965).

54 Both Berkeley and Oakland have developed an isolationist attitude toward planning. Berkeley feels each city must look out for itself and will cooperate with other jurisdictions only when its own interests will be served. Interview 9-L. Similarly, Oakland refers its plans to other jurisdictions only for their information. It considers planning to be entirely an internal matter which concerns no one outside of Oakland. Interview 8-L.

55 In addition to local planning commissions, communities may have zoning boards of adjustment. CAI. Gov'x CODE $\S 65900$ (West 1966). These zoning boards are responsible for the creation and maintenance of zoning ordinances. See id. $\$ 65902$. The division of responsibility between the two bodies, however, is not clear, for in most instances the zoning board consists of planning commissioners who merely change hats when bandling zoning matters. In any event, the planning commission is adequately represented on the zoning board. In Berkeley, for example, three of the five zoning commissioners are also planning commissioners. Interview 7-L. 
citizen[s] . . w willing to serve without compensation."150 They are not professional planners, but are usually lawyers, architects, insurance and real estate brokers, or local businessmen. ${ }^{57}$ The position is part time, and most commissioners only meet formally once or twice a month..$^{58}$

Low income and minority groups are often unrepresented on the commissions..$^{59}$ This pattern of representation, however, may be more a matter of necessity than design. Commission duties require more time than is available to individuals who cannot financially afford to take time off from regular jobs. At present, planning commissioners can only spare a limited amount of time and effort for their planning responsibilities. ${ }^{00}$ In practice, it is impossible for commissioners to do all the required planning for any sizeable jurisdiction. To be sure, the commissioners may have professional planning staffs to do required field work and investigation. ${ }^{\text {B1 }}$ The Staff's influence, however, is not as limited as its duties. Although the commission is officially responsible for initial planning decisions, too often it must act on the basis of the information compiled primarily by its professional staff. ${ }^{2}$ Lacking the time and expertise to evaluate this information, the commission relies heavily upon the staff for its answers. As a result, many planning commissions have been reduced to a mere "rubber stamp" of the professional staff..$^{03}$

Although planning commissions fail adequately to represent all interest groups within the community and rely too heavily on staff recommendations instead of their own considered judgement, they may nevertheless fulfill a valid political purpose. As one professional planner put it, the planning commission acts as a buffer between the technical structure-

56 F. Horack \& V. Nolan, LaNd Use Controls 35 (1955).

${ }^{57}$ Oakland's planning commission is fairly representative. It includes a dentist, an insurance salesman, a member of the League of Women Voters, a retired attorney, an executive of a wholesale lumber company, a realtor and an architect. Interview 8-L.

58 F. Horack \& V. NolAN, supra note 56, at 34 . The number of meetings varies among jurisdictions. Berkeley's commission meets formally once a month, but usually meets three or four times informally to handle the heavy work loads. Interview 7-L. Oakland's commission meets formally three times a month and informally when necessary. Interview 8-L.

59 This lack of minority interest representation is a concern to San Francisco residents.

San Francisco Chromicle, March 9, 1967, at 4, col. 1.

co Of fourteen planning commissioners asked for interviews, ten said they would be very happy to discuss their positions and duties but that, because of their private businesses, time did not permit.

61 CAX. Gov'T CoDE $\S 65200$ (West 1966); see discussion accompanying notes 66-67 infra.

62 Some information is also received from the public hearings. See text accompanying notes 33-35 supra,

03 See Comment, supra note 40, at 107-08. See also F. HoRACr \& V. Nolan, supra note 56, at 34-35. In Berkeley, the zoning board of adjustment has delegated to the zoning administrator the power to decide on various applications if, in the administrator's opinion, the matter is non-controversial and does not require full board attention. Interview 7-I. 
oriented bias of the staff and the political people-oriented bias of the city council.$^{64}$ Acting as an impartial administrative thermostat, the commission judges the impact of planning decisions upon the community. On more controversial issues, it tends to side with the general public against unpopular staff recommendations. As long as planning commissioners are impartial and conscientious, they at least serve this limited political function in the decision making process.

But this political function may make the commissioners biased when regional issues are concerned. The commissioners have received their positions precisely througl their demonstrated concern for the well-being of their community. ${ }^{65} \mathrm{~A}$ commissioner would find it difficult to recommend to the council a proposal that would benefit the region but burden his own community. A regional approach to planning may also be politically unwise. Althougl the commission is not subject to popular vote, the legislators who appoint them are. Local legislators are directly responsible to their own electorate, not to the region. If the commission took an approach contrary to the local self-interest of the community, political expediency miglit force local legislators to appoint a more cooperative commission.

The same parochialism permeates planning staffs as well. The staff's job is to submit to the commission or council its recommendations on certain planning proposals. Unfortunately, the staff considers only local interests. ${ }^{66}$ Although they are often aware of the regional impact of their decisions, most feel that their job is to plan, not for the region, but for the jurisdiction which employs them. ${ }^{67}$ Even if planning staffs did recommend programs which would primarily benefit the region, their suggestions would probably be rejected. The staff, as well as the commission, only makes recommendations to the city council. The council, in turn, being an elected political body, may find it politically necessary to ignore the objectives of those outside its jurisdiction.

64 Interview 9-L.

${ }^{65}$ See F. HORACK \& V. NOLAN, supra note 56, at 35.

${ }^{60}$ All interviewed staff personnel contrasted what they felt was the best regional approach to planning with the best approach for the particular jurisdiction they represented. A typical response to the question, "Do you favor regional planning?," was "Yes, of course I do, but the city would never stand for it." Interview 8-L.

67 One planner admitted there was a need for regional planning. But when confronted with a hypothetical situation that would benefit the region as a whole but burden his own community, such as the choice between locating all public housing for the region within his community or making his community a repository for all the garbage in the region, he agreed that he was uncertain whether his conviction for the need for regional planning was strong enough to overcome his bias of planning in the best interests of his particular community. Interview 7-L. 


\section{Inadequate Planning Criteria}

(a) Preservation of Community Character-For two basic reasons, local legislators find it politically impractical to consider regional land use needs. First, because each community desires to maintain its own characteristic development, its zoning ordinances may occasionally discriminate against the interests of the region as a whole. A basically residential community, for example, may seek to exclude industrial development and high density apartment buildings. Because this type of development often brings the traffic hazards of congested streets and smoke and water pollution and requires the provision of such costly services as fire and police protection, sanitary facilities, and sclrools, zoning exclusions may serve the local public interest. ${ }^{68}$ Of course the real reason for such an exclusion may be to prevent low income minority groups from entering the neighborhood. ${ }^{69}$ Often, however, this latter motive may go undetected. An unjustifiable land use regulation can be easily couclied in the judicially acceptable terms of protecting the "health, safety, morals or general welfare" of the community. ${ }^{70}$ And once any public interest can be found for this exclusion it will be deemed a valid exercise of local police power.

Quite apart from the intent behind the restriction, a regulation of land for even laudable purposes may detrimentally affect the region as a whole. A community may wish to preserve property values by limiting lot sizes or by zoning only for single family dwellings. ${ }^{71}$ This action, however, by excluding poorer families from the jurisdiction, may disproportionately burden other communities by forcing them to provide sufficient low cost housing for those excluded. ${ }^{2}$ Whether or not a regional body would require the individual localities to ameliorate their restrictions, it is obvious that the communities concerned will not find it in their own interest to

68 See R. Babcock, The Zoning GaMe 144-45 (1966).

69 Most large communities in the Bay Area are extremely sensitive to accusations of racial discrimination through the use of planning tools. Both Oakland and Berkeley have taken pains to avoid zoning restrictions which minority groups have felt would be discriminatory. In two cases, complaints were made that the purpose of restrictions on high density housing was to prevent Negroes from entering the community. In both instances, however, the same interest groups withdrew their opposition and asked the city council to impose these restrictions when they realized that the restrictions were designed not to discriminate, but to avoid overly congested streets, schools and homes. See Interviews 7-I and $8-\mathrm{L}$.

70 See notes 26-28 supra and accompanying text.

71 See R. BABCOCK, supra note 68 , at 20-28, 116-20.

72 In 1960 , for example, Negro residents coniprised $0.6 \%$ of the population of southern Alameda County. For this same period they comprised $22.8 \%$ of Oakland and $19.6 \%$ of Berkeley. Councri of Soctal Pianning, Atameda Countr, Calmornia, Population Trends IN ALAzadeda Cóunty 19-20 (1963). 
do so. Until some authority is capable of controlling land use development on a region-wide basis, parochial regulation will continue to benefit a few to the detriment of many.

(b) Search for a Larger Tax Base.-A second basic reason why local legislators iguore the regional interest in land use regulation concerns property taxation. ${ }^{73}$ Local governments must finance themselves substantially from property taxes. Therefore it is essential that each jurisdiction keep its property values high to sustain a healthy tax base. Because residential property taxes are insufficient to support all community services ${ }^{74}$ revenue must be raised by attracting industry into the community. ${ }^{75}$ This necessity for tax revenue led many Bay Area communities to overzone for industrial development. ${ }^{76}$ The misguided hope of these communities was that zoning an area "industrial" would be sufficient to attract industry. Since each area's supply of industrial space was greater than industry's potential demand, areas had to compete for the available industries. A principle device used was a series of tax incentives offered to individual industries that agreed to estabhish plants in their jurisdictions. ${ }^{77}$ The failure to offer tax incentives deterred industry which might normally consider settling in a jurisdiction and therefore necessitated the imposition of high tax rates throughout the community. ${ }^{78}$

The tax circle is vicious and the effects of competition are detrimental to both locality and region. The locality either fails to attract the industry to support its revenue expectations, or sacrifices the desired residential

73 Interview 7-L. Some planners feel that tax base considerations are presently the controlling factor in local planning, and, if other ways to raise revenue could be devised, the whole concept of local planning would be radically changed. Interviews 8-L and 1-R. The relationship between land use and property taxation is discussed in Comment, 55 CAIIF. L. REv. 856, 858-72 (1967).

74 Interview 9-I.

75 Interview 9-I. Although not as effective as industry in maintaining a healthy tax base, shopping centers and high density apartments can sustain large portions of local property tasation.

76 See ABAG, Prectacinary PLAN, supra note 10, at 18. See text accompanying notes 24-25 supra.

$\mathbf{7 7}$ The incentives usually take the form of decreased property taxes or a reduction in the cost to the industry of needed city services. Interview 2-R.

78 In Berkeley, a himited supply of residential land and soaring real estate prices have resulted in extremely high property taxes. The financial burden these taxes would place on industry is too great to attract new development. To combat this problem, Berkeley plans to construct an industrial park with the use of federal funds. This federally subsidized industrial complex will relieve the industry from paying a high purchase or lease price for its site, making settlement more attractive. Interview 9-I. 
character of the community. ${ }^{79}$ And in either case the region becomes the victim of unguided industrial dispersion.

There is no indication that the present locally based system of planning will be able to handle regional problems in a manner superior to present interest-oriented solutions. It is clear that some other level of government nuust effectively coordinate regional policies and implement their solutions consistently throughout the Bay Area without regard for the parochial preferences of the individual jurisdictions. Either the state or some regional government should be capable of satisfying this requirement. But before anticipating what powers such an authority should have, it is helpful to analyze the present state and regional approaches to land use planning.

\section{II}

\section{STATE AND REGIONAI APPROACHES}

\section{A. State}

State concern with local planning has been minimal. The State Office of Planning, ${ }^{80}$ the sole state agency which can influence local land use planning, is primarily a troubleshooter. Organized under the Department of Finance, ${ }^{81}$ it investigates potential conflicts between other state agencies, confers with the agencies involved and attempts to coordinate action between then. In addition, it inust prepare, maintain, and revise a long-term general plan for the future "physical growth and development of the state." ${ }^{82}$ Through its Planning Advisory Committee ${ }^{83}$ the Office may, in a strictly advisory capacity ${ }^{84}$ assist local and regional planning agencies with local land use problems. ${ }^{85}$ Assistance usually takes the form of offering the services of the Office's expert technical and professional planning staffs and other facilities to local or regional agencies requesting such aid. ${ }^{86}$

As larger communities with their own staffs do not need assistance from the State Office, this arrangement should at least provide smaller

79 Eliminating tax base considerations would not solve the problem of lack of cooperation. If there were no financial advantage in attracting industry, each community would reverse its current efforts to attract industry and would compete to avoid it.

80 CAL. Gov'T CODE $\$ \S 65011.1-20.10$ (West 1966).

81 Id. \& 65013.1 .

$82 I d$. § 65013.2 (a).

83 Id. \& 65020.1. The Governor appoints the eleven unan board. Five represent the counties: two county supervisors, two county planning commissioners, and one county planning director. Five represent the cities: two city councilmen, two city planning commissioners and one city planning director. The last member is a county superintendent of schools representing the school districts. Id. § 65020.2.

84 Id. § 65020.5 .

85 Id. \& 65013.2(e).

88 Id. $\S \S 65017.1,65017.2(2)$. 
communities with professional planning assistance they cannot otherwise afford. Unfortunately, at present, no regional local planning agency has ever received this aid from the State Office. The reasons are twofold. First, because the Office has been operating for only a few years, ${ }^{87}$ most local planning agencies are not familiar with its advisory function. It has therefore never occurred to them to enlist its aid. ${ }^{88}$ Second, and most important, requests for assistance would probably be fruitless. The Office is terribly understaffed ${ }^{89}$ Therefore localities which are aware of the Office's service feel it could not be of much assistance even if they requested its aid, and they have refrained from doing so. ${ }^{.0}$

Under this present system the State Office of Planning does not take an active part in the planning and development of local urban areas. By making the Office's assistance completely optional and advisory, the California legislature has refused to assert any direct control over local planning. To be sure, it is concerned with the effect local planning has on the state as a whole, but it has manifested this concern on the regional level.

\section{B. Regional}

The Regional Planning Law ${ }^{91}$ was enacted in recognition of the need for "harmonious development" of urban areas. ${ }^{92}$ It provides for the Planning Advisory Committee of the State Office of Planning to divide the state into regional districts. ${ }^{93}$ Each district is governed by a "regional planning board" ${ }^{294}$ consisting of appointed representatives of the governing bodies of the cities and counties within the district.5

87 Although created in 1955, the State Office of Planning did not even begin its State Planning Project until 1962. W. Spangere \& P. Sedwax, Municipar, State and Federal Programs Affecting San Francisco Bay 31 (1966).

88 Interviews 7-L and 9-L. One planner stated that to his knowledge no municipality has ever asked for such assistance. It was his opinion that the Office never intended to provide this service. Interview 8-L.

89 The State Office only has three planners in their local planning division. It is inpossible for these men to handle any of the planning requests from local governments. Therefore, as an alternative, the Office has developed a three party contract arrangement between themselves, the local jurisdictions and private planning consultants. When a city or county wants planning aid, it hires a private consultant who techmically contracts with the State Office, which in turn contracts with the jurisdiction to provide the requested service. The reason for the three party contract is that, in order to get certain grants fron the federal government to finance this service, the State Office of Planning must be the sponsoring agency. Interview 6-P.

80 Interview 8-L.

91 CAx. Gov't Code $\$ \$ 65060-69$ (West 1966).

92 Id. $\S 65060.2$ (d).

93 Id. § 65018.2. The Committee has divided the state into twelve districts. Each district must include so far as possible areas with mutual social and commercial interests. Id. § 65018.3.

94 Id. $\S 65063$.

95 Representation is proportional to population. Minimum representation is two per 
The regional board, if it chooses, can "prepare and maintain" a regional plan ${ }^{96}$ after it holds "at least two public hearings in different parts" of the district..$^{97}$ It may pubhsh studies or investigations on regional problems, and it may offer its facilities and services in solving any problems involving two or more local governmental bodies. ${ }^{88}$ Unfortunately, as is the case with the State Office of Planning, all plans and recommendations of the regional planning board are advisory and do not have to be followed by the local governments. ${ }^{99}$

The advisory capacity of the regional planning districts, however, has never been invoked. A regional planning district only comes into existence when two-thirds of both the cities and the counties declare by resolution that such a district is "needed." ming districts organized under the Regional Planning Law. The reasons for this are threefold. First, although planning is a familiar concept among local governments, the need for regional planning which encompasses several jurisdictions has not become apparent until recently. ${ }^{101}$ Second, local governments in California still cling tenaciously to the tradition of "home rule" in local land use planning. ${ }^{102}$ Because they see regional planning under this law as state interference in local affairs, they are afraid of doing anything which miglit increase state control. Third, an alternative to regional land use planning that does not involve state control is currently available.

Under the Joint Powers Act, ${ }^{103}$ two or more governmental bodies can voluntarily contract with each other to perform services that could not

county-one appointed by the county board of supervisors and one appointed by the city councilman within the cities. CAI. Gov'T CODE $\$ 65063.1$ (West 1966). For the method of selection of these representatives see $i d$. \$§ 65062-63.7.

06 Id. § 65065.1(a). A "regional plan" is defined as "a comprehensive, long-term general plan for the physical development of the region, and any land outside its boundaries which ... bears relation to its planning." Id. $\$ 65060.7$.

${ }^{07} I d . \& 65065.1$ (a). In large regional districts the two-meeting requirement is inadequate. In the Bay Area, for example, if such hearings are held in the least populated northern counties (Napa, Sonoma or Solano), it will be difficult for the majority of the people in the southern counties to be effectively heard. To insure effective safeguards, hearings should be held in several parts of the district so that an interested party is not required to travel over fifty miles to attend.

98 CAL. Gov'T CODE $§ 65065.1$ (West 1966).

99 Id. $\$ 65060.8$.

$100 I d$. $\$ 65061.3$.

101 The Regional Planning Law was adopted in 1963. Ch. 1811, § 2 [1963] Cal. Stats. 3669.

102 The California Constitution gives to local governments control over local police powers, CaIIF. Const. art. 11, $\S 11$ (West 1954), and land use regulation has been considered a police power since 1926, Village of Euclid v. Ambler Realty Co., 272 U.S. 365 (1926). This concept of control of local problems by local government is commonly called "home rule." See ABAG APpRaISEd, supra note 10, at 5.

103 CAI. Gov'T CoDE $\$ \S 6500-78$ (West 1966). 
be handled by any one body itself. ${ }^{104}$ Effective regional planning is such a service. In 1961, many communities of the Bay Area joined together, under the Joint Powers Act, to form the Association of Bay Area Governments (ABAG). ${ }^{105}$ The purpose of ABAG was to gain the benefits of voluntary regional planning which would be entirely subject to local control. ${ }^{106}$ At its inception, ABAG's activities were severely restricted. ${ }^{107}$ It reviewed governmental proposals that affected the metropolitan area and conveyed its recommendations to the local governments involved. ${ }^{108}$ In addition, it studied various metropolitan problems and offered suggestions for solving them. ${ }^{109}$ But as its membership and influence grew, it took on added responsibilities. In 1964 ABAG received a "701" grant $t^{110}$ from the federal government for the preparation of an advisory regional master plan and in the same year was recognized by the federal Housing and Home Finance Agency as the official regional planning agency in the Bay Area. ${ }^{111}$ Since 1965 the Housing and Urban Development Act ${ }^{112}$ has made funds available to finance two-thirds of every regional program ABAG might pursue. The funds are to be used to establish and maintain the coordinated development of the entire metropolitan area..$^{113}$

The federal government's recognition of $A B A G$ as the official regional planning agency for the Bay Area has given $A B A G$ powers not anticipated by its founders. Although ABAG cannot legally force member cities and counties to conform to its planning policies, ${ }^{114}$ it can reach this end indirectly. Almost all planning programs of any significance must be

104 See City of Oakland v. Williams, 15 Cal. 2d 542, 103 P.2d 168 (1940).

105 W. Spangle \& P. Sedway, supra note 87 at $60-61$. ABAG consists of appointed representatives of every local legislative body (city and county) in the association. All decisions require a two-thirds approval of both the cities and the counties.

The Regional Planning Law will not operate if two-thirds of the cities and counties are participating in a joint powers agreement. CAI. Gov'T CODE § 65061.4 (West 1966). Planning under the Joint Powers Act is more agreeable to local governments because it permits them to determine what powers such a body will or will not have rather than using the system devised by the state. But see text accompanying notes 114-18 infra.

106 See ABAG AppraISED, supra note 10, at 14-15, 57.

${ }^{107}$ ABAG was given no regulatory power. It was organized solely as "a forum for discussion and study of metropolitan area problems of mutual interest and concern to the counties and cities in the San Francisco Bay Area." Preamble to the By-Laws of the Association of Bay Area Governments (1961).

108 ABAG By-Laws, art. 1, § A.

$109 \mathrm{Id}$. \& B.

110 "701" grants are matching grants provided to state and local governments under $\S 701$ of the U.S. Housing Act of 1954, 68 Stat. 640 (1954), as amended, 40 U.S.C. $\S 461$ (Supp. I, 1965).

111 W. Spatare \& P. Sedway, supra note 87 , at 61.

11240 U.S.C. \& 461 (Supp. I 1965).

113 See ABAG APPRAISED, supra note 10, at 58.

114 Members may withdraw from ABAG at any time. For the procedure for withdrawal, see ABAG By-Laws, art XI. 
financed largely through federal funds. ${ }^{115}$ Before any local jurisdictions can obtain these funds, it must first receive the approval of the recognized regional planning agency in the area. ${ }^{116} \mathrm{ABAG}$ will only give its approval when it feels that the local plan is in the best interests of the region. ${ }^{117}$ In this way the federal government guides the use of its funds in a manner that will produce orderly cooperative development of the region. ${ }^{118}$

ABAG considers this power over federal funds insufficient to maintain regional cooperation. It is presently endorsing a bill now before the state legislature to give $A B A G$ the power to levy taxes, issue bonds and exercise the right of eminent domain. ${ }^{119}$ These powers will enable ABAG to enforce effectively those regional plans it creates. However, the lack of support among member jurisdictions for this proposal dramatically illustrates the difficulties in convincing individual localities of the need for unified regional planning and control. ${ }^{120}$ Whether or not $A B A G$ prevails in this present debate may significantly affect the growth of the metropolitan Bay Area. If $A B A G$ obtains the power to require all cities and counties in the Bay Area to act in accordance with a regional plan, it may achieve cooperative regional planning. But until then, $A B A G$ will remain a volun-

115 Urban redevelopment programs afford a prime example of the need for federal funds. See Comment, 55 CazIF. L. Rev. 813, 819 (1967).

${ }^{116}$ Although no federal law gives ABAG a veto power, as a matter of federal policy it has one. See San Jose Mercury, April 8, 1967, at 21, col. 4.

117 Interview 1-R. See also ABAG ApPraISED, supre note 10, at 58. ABAG also has a veto power over federally financed state programs within the region. San Francisco Chronicle, Feb. 8, 1967, at 38, col. 7 .

118 At least one ABAG planner, apparently in a minority, considers this power sufficient to exercise effective control over regional development. Interview 1- $R$.

119 See Assoctation of Bay Area Governarents Regional Home Rute and GoversMEENT OF THE BAy AREA, Exhibit C (1966). See also A.B. 50 and S.B. 26, Cal, 1967 Sess.

120 ABAG's desire for additional power has caused some local member governments to reexamine the objectives of a cooperative regional body. Many menbers feel that ABAG is attenipting to go too far and should remain a voluntary advisory organization. Statement by the representative of the city of Millbrae at the meeting of the General Assembly of ABAG, November 7, 1966, at the Claremont Hotel in Berkeley. See also ABAG Goals \& Organization Comm., Report to the General Assembly, November 30, 1966, at 6. Others have shown their opposition by withdrawing or by threatening withdrawal. San Francisco Chronicle, March 22, 1967, at 3, col. 3. Oakland opposes granting these new powers but is fearful of pulling out because it may mean the loss of needed federal funds. San Francisco Chronicle, March 17, 1967 at 6, col. 7.

On the other hand, a nunber of menbers feel that ABAG should assume even further responsibility for functions presently handled by state special districts. They want to sce ABAG take over the job now handled by the Bay Conservation and Development Commission, the Bay Area Transportation Study Commission and the Air Pollution Control District. See Goals \& Organization Comm. Report, supra at 4. And still others are satisfied with the functions ABAG wishes to assume but are afraid that in so doing ABAG might violate the principles of "one man one vote" representation. Statements by the representatives to ABAG from cities of Oakland and San Francisco and the county of Sonoma at the meeting of ABAG's General Assembly at the Claremont Hotel in Berkeley, November 7, 1966. 
tary organization with no effective way to insure the harmomous growth of the Bay Area.

\section{CONCLUSION}

New approaches to regional land use problems in the San Francisco Bay Area must be found. If present trends continue, the future will be characterized by increasingly competitive parochial legislation accompanied by effects imcreasingly detrimental to the entire Bay Area. Existing state, regional and local approaches to planning are seriously inadequate. The only present control over the orderly growth and development of the entire region is ABAG's authority over federal planning funds. ${ }^{121}$ Because significant planning programs today depend upon federal aid, regional planning agencies, by restricting available funds to those local agencies which follow a regional plan, can force the localities to cooperate to a himited degree. But this approach is not an effective alternative to a future regional government, for much planning in the Bay Area does not require federal aid. Restrictive zoning policies, for example, may liave a significant impact on regional growth and development, yet can be implemented by simply changing local zoning ordinances. ${ }^{122}$

Effective control over land use planning in the Bay Area requires the creation of a nine-county metropolitan government. ${ }^{123}$ This regional government must receive the power to prepare and maintain a regional plan for the entire Bay Area. It must also receive the powers now existing in local municipal governments which are necessary to enforce regional land use regulation, and its governing board should be elected directly by the people residing in the district to give them adequate representation. If such a government can be effectively created, the Bay Area will become a more viable arena for growth. A regional government, whicli owes its allegiance to the entire Bay Area, will "suffer" from regional parochialism. It will more than likely favor the best interests of the region as a whole rather than those of one particular locahity.

Steven $H$. Goldfarb

121 See notes 111-18 supra and accompanying text.

122 See notes 45-46 supra and accompanying text.

123 Because many areas in the northern and eastern counties have little or no relation to the planning interests of the Bay Area metropolis, their inclusion in the district is not necessary for adequate planning. But unless the metropolitan government were to take over all of the functions of the counties, including fire and police protection, it would be more efficient for the jurisdictions of the counties and the metropolitan government to coincide. 